Egyptian Journal of Aquatic Biology \& Fisheries

Zoology Department, Faculty of Science,

Ain Shams University, Cairo, Egypt.

ISSN $1110-6131$

Vol. 22(5): 73-85 (2018)

ejabf.journals.ekb.eg

\title{
Monitoring some pathogenic bacteria in water and fish of Lake Qaroun
}

\author{
Noha M. Sabry ${ }^{1}$, Sahar T. M. Tolba ${ }^{2} *$, Fagr Kh. Abdel-Gawad ${ }^{1}$ \\ 1- Centre of Excellence for Advanced Science (CEAS), Water Pollution Research \\ Department, National Research Centre, Giza, Egypt. \\ 2- Department of Microbiology, Faculty of Science, Ain Shams University, Egypt. \\ *Corresponding author: saharaak@hotmail.com; s.tolba@sci.asu.edu.eg
}

\section{ARTICLE INFO \\ Article History: \\ Received: Sept. 26, 2018 \\ Accepted:Oct. 20, 2018 \\ Available online: Nov. 2018}

\section{Keywords:}

Lake Qaroun

Pathogenic bacteria

S. auerus

Aeromonas hydrophila

Tilapia zillii

Mugil cephalus

\begin{abstract}
Water quality plays a vital role in the productivity of lake's fish. Lake Qaroun is exposed to untreated agricultural, domestic and industrial effluents which are considered serious pollutents. This study was conducted to monitor the water quality of the lake and the pathogenic bacteria in the surface water and fish. Physico-chemical parameters of water and bacterial count of water and two types of fish Tilapia zillii and Mugil cephalus were studied. Samples were collected from four sites at certain distances from El-Batts drain in the lake during 2015-2016. Physical characteristics of the water showed that the water temperature varied between 16 and $30^{\circ} \mathrm{C}, \mathrm{pH}$ was alkaline. Water salinity and disolved oxygen decreased near El-Batts drain, while the chemical oxygen demand, amonia and nitrate levels were high due to the pollution and bacterial activity. Bacteriological characteriztion revealed that the bacterial load in the nearest point to El-Batts drain was higher than the other examined sites of lake water. The total and fecal coliform near El-Batts drain exceeded the Egyptian standard limits; it reached $4.4 \times 10^{7}$ in summer. The study revealed that the bacterial pathogens counts in fish were high in mullet species than that of tilapia. Total and fecal coliforms were detected in muscles once during the study period; in spring for tilapia and in summer for mullet fish. The study revealed that Aeromonas hydrophila was the most prevalant pathogen isolated from Tilapia zillii and Mugil cephalus and that $72 \%$ of $A$. hydrophila harboured aerolysin toxin gene. $A$. hydrophila was detected in muscles of both tilapia and mullet during the four seasons through 12 months, while $S$. aureus and $P$. aeruginosa were detected only in summer or spring. The study highlights the hazardous effect of the untreated domestic and industrial drainage wastes on water quality and fish of Lake Qaroun.
\end{abstract}

\section{INTRODUCTION}

Lake Qaroun is an enclosed, saline, highly eutrophied lake in Egypt, it is far forty-five meters below sea level into the lowest, northern section of El- Fayoum Depression. It is one of the most polluted lakes, which is exposed to continuous environmental changes. Many authors reported changes in water quality of Qaroun lake (Abou El-Geit et al., 2013; Haroon et al., 2018).

Lake monitoring may provide early warning signs of ecosystem degradation resulting for example from contaminant inputs, nutrient addition, and sediment run 
off. By monitoring the physical, chemical, and biological status of a lake, changes for many aspects of the ecosystem can be detected quickly (Leiser et al., 2015).

Fish is an important source of cheap, high nutritive animal proteins. Fishing is an important economic activity in many countries. In this way, the Egyptian Government paid special interest to fish meat within its strategy of the food security (Elsayed et al., 2018). Microbiological quality of Qaroun lake water is frequently, threatened by contamination with untreated domestic wastewater. Bacterial pathogens are a great threat to fish production worldwide due to the high economic importance of diseases they cause (Wamala et al., 2018). Aeromonas, Staphylococcus and Pseudomonas species were determined in many previous studies because they are among the economically important bacterial fish causing diseases affecting fish cultures (Falaise et al., 2016; El-Gamal et al., 2018).

It is difficult to fully recognize the bacterial load of water bodies. The chemistry of water reveals much about the metabolism of the ecosystem and explain the general hydro-bacterial relationship (Patil et al., 2012). Therefore, the current study was conducted to evaluate the water and fish quality of Qaroun lake during a year. To achieve this aim physiochemical analysis in addition to bacteriological counts of bacterial indicator (total and fecal coliforms) and some pathogenic bacteria (A. hydrophila, S. aureus and P. aeruginosa) were investigated.

\section{MATERIALS AND METHODS}

\section{Study area}

In the present study, water and fish samples were collected from Qaroun lake seasonally during 12 months from November 2015 to October 2016. Lake Qaroun is found between longitudes of $30^{\circ} 24^{`} \& 30^{\circ} 49^{`} \mathrm{E}$ and latitude of $29^{\circ} 24^{`} \& 29^{\circ} 33^{`} \mathrm{~N}$ Figure (1). It's finite from its northern part by the desert and by agricultural land from its south and south eastern part (Hussein et al., 2008; Haroon et al., 2018). The lake receives agricultural discharged water from the encircling agricultural land. The discharge water enters the lake by two enormous drains; El-Batts drain which lies at the northeast side while El-Wadi drain lies near mid-point of the southern coast.

\section{Sampling of water and fish}

Water samples were collected from four sites as shown in Figure (1), site I: 2 Km after El-Batts drain, site II: $4 \mathrm{Km}$ after El-Batts drain, site III: $8 \mathrm{Km}$ after ElBatts drain and site IV: $12 \mathrm{Km}$ after El-Batts drain. In addition, two common species of fish in Qaroun lake, tilapia (Tilapia Zillii) and mullet (Mugil cephalus) were collected. Water samples were collected from the middle of the stream $30 \mathrm{~cm}$ deep from the surface.

One liter sterile glass bottles for collecting water samples used for bacteriological examination and two liters plastic bottles were used for physiochemical analysis. Samples were transferred in an ice box within 2-4 hours of collection to the laboratory at national Research Center (NRC) for analyses. Fish were collected from the same locations and transferred alive in sterile plastic bags in ice box to the laboratory for bacteriological examination. 


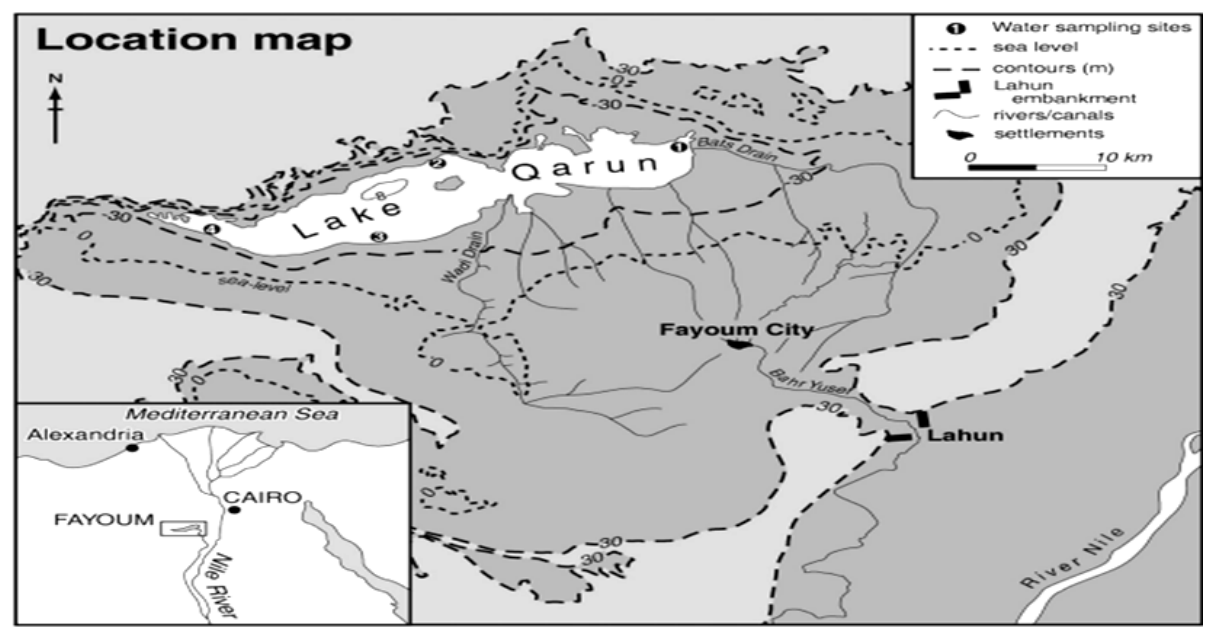

Fig. 1: Location map of lake Qaroun showing the four different sampling sites. Site (1): $2 \mathrm{Km}$, site (2): $4 \mathrm{Km}$, site (3): $8 \mathrm{Km}$ and site (4): $12 \mathrm{Km}$ after El-Batts drain.

\section{Physicochemical characterization of water samples:}

The physical and chemical parameters (temperature, $\mathrm{pH}$, salinity, dissolved oxygen (DO), chemical oxygen demand (COD), ammonia, nitrite, nitrate and total phosphorus) were determined according to APHA, (2012).

\section{Preparation of samples for bacteriological examination:}

Ten $\mathrm{ml}$ of water sample were transferred to $90 \mathrm{ml}$ of $0.9 \% \mathrm{NaCl}$ solution, Tenfold dilution was carried out. The collected fish samples were externally washed twice by distilled water and then by $70 \%$ ethanol. Fish were dissected and $10 \mathrm{~g}$ of each of the three organs (muscle, liver and gills) were homogenized separately and were transferred to $90 \mathrm{ml}$ of $0.9 \% \mathrm{NaCl}$ solution (APHA, 2012).

\section{Determination of total and fecal coliforms:}

Total and fecal coliforms were determined in water and fish samples by the most probable number techniques (MPN) according to APHA, (2012).

\section{Detection and isolation of pathogenic bacteria}

Isolation of Aeromonas hydrophila was carried out by surface plate technique, $0.1 \mathrm{ml}$ of water and tissue samples were transferred on to the surface of $\mathrm{m}$-Aeromonas medium for the detection of Aeromonas hydrophila (Rippey and Cabelli, 1979). Suspected colonies of yellow and green colors were counted and calculated as (CFU/g) for tissue and (CFU/100ml) for water samples. Typical colonies were picked for further confirmation by several biochemical tests as stated in El-Taweel (2003) and Abd-El-Malek(2017).

For detection of $S$. aureus, $0.1 \mathrm{ml}$ of water and tissue samples were cultured on the surface of Vogel and Johnson agar plates (Vogel and Johnson, 1960). Typical colonies with black, shiny, convex colonies with clear zones were counted as CFU/g tissue, CFU/100 ml water were calculated.

Pseudomonas aeruginosa was detected by the most probable number technique (MPN) according to APHA, (2012). A $0.1 \mathrm{ml}$ of each sample of water and fish tissues was inoculated in 3 asparagine broth medium tubes. The tubes were incubated at $37{ }^{\circ} \mathrm{C}$ for $24 \mathrm{~h}$, then examined under ultraviolet light. Production of a green fluorescent pigment constitutes a positive presumptive test. For isolation of Pseudomonas aeruginosa, $0.1 \mathrm{ml}$ from the positive culture was transferred onto the surface of acetamide agar. Purple- red color was developed within 24 to $36 \mathrm{~h}$ of incubation at $37^{\circ} \mathrm{C}$ around the colony was a positive confirmatory test 
for Pseudomonas aeruginosa. Results were computed and reported from the table of MPN determination. Typical colonies were picked from acetamide agar for further work.

\section{Identification of pathogenic bacteria}

Isolates of $S$. aureus and Pseudomonas aeruginosa were identified using BIOLOG GEN III system (BIOLOG, USA). Each isolate was streaked onto TSA plate and incubated at $37^{\circ} \mathrm{C}$ for $24 \mathrm{~h}$. Then a single colony from TSA plate was inoculated on BIOLOG GEN III microplate, incubated at $37^{\circ} \mathrm{C}$ for $24 \mathrm{hrs}$. The reading was carried out automatically by the computerized MicroStation ${ }^{\mathrm{TM}}$ system. While isolates of Aeromonas hydrophila were identified by amplification of a specific virulence gene (aerolysin gene) by PCR (Oliveira et al., 2012).

\section{Molecular detection of aerolysin gene in Aeromonas hydrophila isolates}

One colony was picked from the isolate and mixed with $100 \mu$ lof Ultrapure water for PCR, boiled for $10 \mathrm{~min}$ in thermocycler and $2 \mu \mathrm{l}$ of each was used as DNA template. PCR was carried out on an Applied Biosystem (9700) Thermocycler. The primer pair aer-F (5'CCTATGGCCTGAGCGAGAAG-3' and aerR(5'-CCAGTTCCAGTCCCACCACT -3') were used to amplify a 431-bp of aerolysin gene (Howard et al., 1987), The PCR mixture containing $2 \mu \mathrm{l}$ of template DNA and $4 \mu \mathrm{l}$ of a mixture containing each dNTPs at $0.2 \mathrm{mM}$ (Promega), $2.5 \mu 1$ of a $25 \mathrm{mM} \mathrm{MgCl} 2$ solution ( $3.0 \mathrm{mM}$ final concentration), $0.25 \mu 1$ of a 200 $\mathrm{mM}$ solution of each primer $(1 \mu \mathrm{M}$ final concentration), $0.8 \mu \mathrm{l}$ of Taq polymerase $(5 \mathrm{u} / \mu \mathrm{l}$, Promega), $2.5 \mu 1$ of $10 \mathrm{x}$ PCR buffer and $14.45 \mu 1$ of sterile double distilled water, to make the final volume of $25 \mu \mathrm{l}$. PCR protocol was performed as the following conditions: a denaturation cycle at $94^{\circ} \mathrm{C}$ for $2 \mathrm{~min}$., followed by 35 cycles of denaturation at $94^{\circ} \mathrm{C}$ for 30 sec., $55^{\circ} \mathrm{C}$ for $30 \mathrm{sec}$. and an extension step at $72^{\circ} \mathrm{C}$ for $30 \mathrm{sec}$. and a final extension cycle at $72^{\circ} \mathrm{C}$ for $10 \mathrm{~min}$. The PCR amplicons were analyzed by electrophoresis on $2 \%$ agarose gel stained with $0.05 \%$ ethidium bromide. The gel was visualized by U.V transilluminator (IN Geniuse 3).

\section{Statistical Analysis:}

One way analysis of variance (ANOVA) and values were expressed as the means \pm SE. All statistical tests were performed using of SPSS for Windows Version 14.1.

\section{RESULTS}

\section{Physico-chemical characteristic of Lake Qaroun}

Physico-chemical characteristics of four Sub-surface water samples along Lake Qaroun as recorded in Table (1), were studied. The temperature of the water was extended between a minimum of $16{ }^{\circ} \mathrm{C}$ in winter and a maximum of $30{ }^{\circ} \mathrm{C}$ in summer, $\mathrm{pH}$ ranged from 7.4 to 8.2. Salinity of the lake's surface water revealed that the lowest value was $14.1 \mathrm{~g} / 1$ and the maximum value was $32.9 \mathrm{~g} / \mathrm{l}$.

The lowest dissolved oxygen value was $4.1 \mathrm{mg} \mathrm{O}_{2} / 1$ in site $\mathrm{I}$, while the highest was $8.7 \mathrm{mg} \mathrm{O}_{2} / 1$ in site IV.

The highest chemical oxygen demand (COD) value was recorded in summer in site I (194 mg/l). The highest values of ammonia, nitrates and nitrite values were recorded in site I while they were not detected in sites III and IV Table (1).

\section{Bacteriological analysis of Lake Qaroun water}

Total and fecal coliform counts of the four sites were determined by the MPN method as shown in Table (2). The maximum MPN index $/ 100 \mathrm{ml}$ value of total coliforms in water was detected in summer in site (I) with value $4.4 \times 10^{7}$, and the maximum fecal coliform count was $8.0 \times 10^{5}$ in site (II), While, the minimum MPN- 
index $/ 100 \mathrm{ml}$ value of total and fecal coliform were detected in winter in site (IV) with values $1.6 \times 10^{4}$ and $3.0 \times 10^{3}$ respectively ( Table 2 ).

Table 1: Physico-chemical parameters of water samples collected from Lake Qaroun during the year (2015-2016).

\begin{tabular}{|c|c|c|c|c|c|c|c|c|}
\hline \multirow{2}{*}{$\begin{array}{l}\text { Physico-chemical } \\
\text { parameters }\end{array}$} & \multirow[b]{2}{*}{ Season } & \multicolumn{4}{|c|}{ Source of water (sites) } & \multicolumn{2}{|c|}{ Average } & \multirow{2}{*}{$\begin{array}{l}\text { Permissible } \\
\text { Limits* }\end{array}$} \\
\hline & & Site I & Site II & Site III & Site IV & Min. & Max. & \\
\hline \multirow{4}{*}{ Temperature $\left({ }^{\circ} \mathrm{C}\right)$} & Winter & $17^{\circ} \mathrm{C}$ & $18^{\circ} \mathrm{C}$ & $16^{\circ} \mathrm{C}$ & $17^{\circ} \mathrm{C}$ & $16^{\circ} \mathrm{C}$ & $18^{\circ} \mathrm{C}$ & \multirow{4}{*}{$<35^{\circ} \mathrm{C}$} \\
\hline & Spring & $18^{\circ} \mathrm{C}$ & $17 \circ \mathrm{C}$ & $26^{\circ} \mathrm{C}$ & $28^{\circ} \mathrm{C}$ & $17^{\circ} \mathrm{C}$ & $26^{\circ} \mathrm{C}$ & \\
\hline & Summer & $25^{\circ} \mathrm{C}$ & $28^{\circ} \mathrm{C}$ & $29^{\circ} \mathrm{C}$ & $30^{\circ} \mathrm{C}$ & $25^{\circ} \mathrm{C}$ & $30^{\circ} \mathrm{C}$ & \\
\hline & Autumn & $18^{\circ} \mathrm{C}$ & $17^{\circ} \mathrm{C}$ & $17^{\circ} \mathrm{C}$ & $19^{\circ} \mathrm{C}$ & $17^{\circ} \mathrm{C}$ & $19^{\circ} \mathrm{C}$ & \\
\hline \multirow{4}{*}{$\mathrm{pH}$} & Winter & 7.3 & 7.5 & 7.4 & 7.5 & 7.3 & 7.5 & \multirow{4}{*}{$6.0-9.0$} \\
\hline & Spring & 7.5 & 7.9 & 7.5 & 7.4 & 7.4 & 7.9 & \\
\hline & Summer & 8.2 & 8.1 & 7.9 & 7.8 & 7.8 & 8.2 & \\
\hline & Autumn & 7.6 & 7.4 & 7.5 & 7.2 & 7.2 & 7.6 & \\
\hline \multirow{4}{*}{ Salinity (g/l) } & Winter & 14.10 & 19.86 & 28.50 & 29.49 & 14.10 & 29.49 & \multirow{4}{*}{--} \\
\hline & Spring & 16.65 & 23.42 & 30.40 & 32.32 & 16.65 & 32.32 & \\
\hline & Summer & 17.90 & 27.56 & 32.22 & 34.90 & 17.90 & 34.90 & \\
\hline & Autumn & 14.50 & 21.75 & 29.80 & 30.20 & 14.50 & 30.20 & \\
\hline \multirow{4}{*}{$\mathrm{DO}\left(\mathrm{mg} \mathrm{O}_{2} / \mathrm{l}\right)$} & Winter & 4.9 & 6.5 & 8.3 & 8.0 & 4.9 & 8.3 & \multirow{4}{*}{$>4$} \\
\hline & Spring & 4.3 & 6.4 & 7.6 & 6.5 & 4.3 & 7.6 & \\
\hline & Summer & 4.1 & 5.7 & 6.1 & 6.3 & 4.1 & 6.3 & \\
\hline & Autumn & 4.7 & 6.7 & 7.8 & 8.7 & 4.7 & 8.7 & \\
\hline \multirow{4}{*}{$\mathrm{COD}\left(\mathrm{mg} \mathrm{O}_{2} / \mathrm{l}\right)$} & Winter & 118 & 88 & 65 & 35 & 35 & 118 & \multirow{4}{*}{$<60$} \\
\hline & Spring & 140 & 95 & 90 & 47 & 47 & 140 & \\
\hline & Summer & 194 & 103 & 98 & 55 & 55 & 194 & \\
\hline & Autumn & 128 & 90 & 78 & 42 & 42 & 128 & \\
\hline \multirow{4}{*}{ NH4- N(mg N/l)/ } & Winter & 0.95 & 0.014 & ND & ND & 0.014 & 0.95 & \multirow{4}{*}{$<0.5$} \\
\hline & Spring & 1.34 & 0.023 & ND & ND & 0.023 & 1.34 & \\
\hline & Summer & 1.48 & 0.04 & 0.026 & ND & 0.04 & 1.48 & \\
\hline & Autumn & 0.46 & 0.010 & 0.022 & ND & 0.01 & 0.46 & \\
\hline \multirow{4}{*}{ NO2 (mg NO2/1) } & Winter & 0.10 & 0.008 & ND & ND & 0.008 & 0.1 & \multirow{4}{*}{$<0.3$} \\
\hline & Spring & 0.23 & 0.03 & ND & ND & 0.03 & 0.23 & \\
\hline & Summer & 0.64 & 0.05 & 0.04 & ND & 0.04 & 0.64 & \\
\hline & Autumn & 0.04 & 0.02 & ND & ND & 0.02 & 0.04 & \\
\hline \multirow{4}{*}{ NO3 (mg NO3/l) } & Winter & 0.8 & ND & ND & ND & 0.8 & 0.8 & \multirow{4}{*}{$11.3-45$} \\
\hline & Spring & 1.3 & 0.07 & ND & ND & 007 & 1.3 & \\
\hline & Summer & 1.7 & 0.09 & ND & ND & 0.09 & 1.7 & \\
\hline & Autumn & 0.9 & 0.06 & ND & ND & 0.06 & 0.9 & \\
\hline \multirow{4}{*}{$\mathrm{TP}(\mathrm{mg} / \mathrm{l})$} & Winter & 0.5 & 0.4 & 0.1 & 0.12 & 0.1 & 0.5 & \multirow{4}{*}{1.0} \\
\hline & Spring & 1.4 & 0.7 & 0.2 & 0.18 & 0.18 & 1.4 & \\
\hline & Summer & 1.2 & 0.8 & 0.4 & 0.2 & 0.2 & 1.2 & \\
\hline & Autumn & 1.0 & 0.2 & 0.1 & 0.15 & 0.1 & 1.0 & \\
\hline
\end{tabular}

* Permissible Limits of Egypt legislation of the national law 48/1982. (DO), dissolved oxygen, (COD) chemical oxygen demand, (TP): total phosphorus, ND: not detected

The highest CFU/100 $\mathrm{ml}$ of $A$. hydrophila was $8.7 \times 10^{4}$ in summer in site (I). On the other hand, the lowest value was $1.0 \times 10^{2} \mathrm{CFU} / 100 \mathrm{ml}$ in winter in site (IV). Whereas, the highest CFU value of $S$. aureus was $3.5 \times 10^{4}$ in site (I) in spring, while, the lowest was $1.2 \times 10^{2}$ in winter in site (IV). Moreover, the maximum MPNindex/100 $\mathrm{ml}$ value of $P$. aeruginosa was $4.2 \times 10^{3}$ in summer in site (I), while the minimum value was $1 \times 10^{2}$ in spring and it was not detected in autumn or winter Table (2). It was noticed that the average count of both total and fecal coliform and the three marker bacterial species were higher in summer and in samples collected from site I (near the Batts drain) than the rest of the sites.

\section{Bacteriological analysis of Lake Qaroun fish:}

The MPN values of total coliforms in tilapia and mullet fish (muscle, liver and gills) was recorded in Table (3). Bacterial count was higher in mullet than tilapia and 
the highest total coliform was recorded in gills. The highest MPN value in mullet gills was $3.6 \times 10^{5}$ and in tilapia gills $2.6 \times 10^{5}$. Fecal coliform in mullet and tilapia gills were $3 \times 10^{5}$ and $3.2 \times 10^{5}$ respectively. The count of total and fecal coliform was also higher in mullet liver than tilapia. The lowest count was recorded in fish muscles, it has been noticed that total and fecal coliform was detected once during the year in spring for tilapia and in summer for mullet fish.

The bacterial and MPN counts of A. hydrophila, S. aureus and P. aeruginosa throughout 12 months was recorded in Table (3). The bacterial count of the 3 pathogens was higher in mullet than in tilapia. Spring and summer showed higher count than winter and autumn. The highest bacterial count was recorded in gills followed by liver and the lowest number was recorded in muscles. Detection of the 3 pathogenic markers showed that the number in mullet was higher than in tilapia and the highest numbers were recorded in summer.

The number of $A$. hydrophila, S. aureus and P. aeruginosa in mullet fish gills in summer were $5 \times 10^{5}, 4.8 \times 10^{5}$ and $6.1 \times 10^{4} \mathrm{CFU} / \mathrm{g}$ respectively, while in tilapia the counts were $3.5 \times 10^{5}, 4.4 \times 10^{5}, 4.6 \times 10^{3}$ respectively. Whereas the number of $S$. aureus in liver tissue in both mullet and tilapia were higher than A. hydrophila. The lowest number of pathogenic bacteria was recorded in muscles, it was found that $A$. hydrophila was detected in few numbers in muscles of tilapia and mullet throughout the four seasons while both $S$. aureus and $P$. aeruginosa were detected only once in muscle in summer.

Table 2: Bacteriological analysis of water samples collected from Lake Qaroun during the year (2015-2016)

\begin{tabular}{|c|c|c|c|c|}
\hline \multirow[t]{2}{*}{ Season } & Site I & Site II & Site III & Site IV \\
\hline & \multicolumn{4}{|c|}{ TCx10 $^{5} \mathrm{MPN}_{100 \mathrm{ml}^{-1} / \text { Site }}$} \\
\hline Winter & $0.71 \pm 1.2$ & $0.28 \pm 0.7$ & $0.19 \pm 1.1$ & $0.16 \pm 1.3$ \\
\hline Spring & $5.36 \pm 1.0$ & $4.96 \pm 0.7$ & $2.20 \pm 0.6$ & $3.30 \pm 0.9$ \\
\hline Summer & $443 \pm 1.2$ & $80.0 \pm 0.5$ & $30.0 \pm 0.8$ & $26.0 \pm 1.0$ \\
\hline Autumn & $2.8 \pm 0.9$ & $0.43 \pm 0.2$ & $0.22 \pm 0.4$ & $0.21 \pm 0.7$ \\
\hline \multicolumn{5}{|c|}{ FCx10 ${\mathrm{MPN} 100 \mathrm{ml}^{-1} / \text { Site }}^{5}$} \\
\hline Winter & $0.02 \pm 1.3$ & $0.02 \pm 0.5$ & $0.04 \pm 0.6$ & $0.03 \pm 0.5$ \\
\hline Spring & $0.12 \pm 2.0$ & $0.33 \pm 0.9$ & $0.26 \pm 0.1$ & $0.21 \pm 0.2$ \\
\hline Summer & $2.6 \pm 2.2$ & $8.0 \pm 1.6$ & $5.3 \pm 0.5$ & $3.0 \pm 0.1$ \\
\hline Autumn & $0.18 \pm 0.7$ & $0.24 \pm 0.8$ & $0.28 \pm 0.7$ & $0.25 \pm 0.6$ \\
\hline \multicolumn{5}{|c|}{$\mathrm{AHx10}^{3}$ CFU $100 \mathrm{ml}^{-1} /$ Site } \\
\hline Winter & $2.0 \pm 0.6$ & $0.6 \pm 1.6$ & $0.30 \pm 1.9$ & $0.1 \pm 0.03$ \\
\hline Spring & $49.0 \pm 1.1$ & $2.4 \pm 0.9$ & $3.30 \pm 0.5$ & $0.38 \pm 0.1$ \\
\hline Summer & $87.0 \pm 1.4$ & $3.9 \pm 0.8$ & $0.40 \pm 1.4$ & $0.24 \pm 0.5$ \\
\hline Autumn & $6.0 \pm 0.4$ & $3.0 \pm 2.3$ & $0.20 \pm 0.8$ & $0.19 \pm 0.4$ \\
\hline \multicolumn{5}{|c|}{$\mathrm{SAx10}^{3} \mathrm{CFU}$ 100 $^{-1} /$ Site } \\
\hline Winter & $2.0 \pm 1.2$ & $0.17 \pm 0.6$ & $0.16 \pm 0.9$ & $0.12 \pm 0.3$ \\
\hline Spring & $35.0 \pm 1.8$ & $2.4 \pm 0.4$ & $2.3 \pm 0.1$ & $0.21 \pm 0.1$ \\
\hline Summer & $28.0 \pm 0.4$ & $4.8 \pm 1.1$ & $0.41 \pm 0.4$ & $0.30 \pm 0.6$ \\
\hline Autumn & $3.0 \pm 0.7$ & $2.0 \pm 0.9$ & $0.18 \pm 0.7$ & $0.14 \pm 0.8$ \\
\hline \multicolumn{5}{|c|}{ PAx10 $^{3} \mathrm{MPN} 100 \mathrm{ml}^{-1} /$ Site } \\
\hline Winter & $0.46 \pm 0.2$ & $0.03 \pm 0.8$ & $0.01 \pm 0.9$ & ND \\
\hline Spring & $1.8 \pm 0.4$ & $1.3 \pm 0.3$ & $0.18 \pm 0.6$ & $0.1 \pm 0.6$ \\
\hline Summer & $4.2 \pm 1.7$ & $0.3 \pm 1.5$ & $0.52 \pm 1.9$ & $0.2 \pm 0.7$ \\
\hline Autumn & $2.8 \pm 0.5$ & $0.1 \pm 0.7$ & $0.02 \pm 0.8$ & ND \\
\hline
\end{tabular}

*TC: Total coliform; FC: Fecal coliform; AH: Aeromonas hydrophila; SA: Staphylococcus aureus and PA: Pseudomonas aeruginosa 
Table 3: Bacteriological analysis of tilapia and mullet fish samples collected from Lake Qaroun during the year 2015-2016.

\begin{tabular}{|c|c|c|c|c|c|c|}
\hline \multirow{3}{*}{ Season } & \multicolumn{3}{|c|}{ Tilapia } & \multicolumn{3}{|c|}{ Mullet } \\
\hline & \multicolumn{6}{|c|}{$\mathrm{TCx}^{3} \mathrm{MPN}^{3} \mathrm{~g}^{-1} /$ Site } \\
\hline & Muscle & Liver & Gills & Muscle & Liver & Gills \\
\hline Winter & ND & $0.24 \pm 0.8$ & $5.2 \pm 0.9$ & ND & $0.35 \pm 1.2$ & $5.8 \pm 0.9$ \\
\hline Spring & $0.2 \pm 0.7$ & $5.2 \pm 2.1$ & $26.0 \pm 0.7$ & ND & $5.1 \pm 2.1$ & $49.0 \pm 2.3$ \\
\hline Summer & ND & $400 \pm 0.5$ & $2600 \pm 0.6$ & $0.4 \pm 1.5$ & $62.0 \pm 2.0$ & $3600 \pm 1.7$ \\
\hline Autumn & ND & $0.7 \pm 1.3$ & $43.0 \pm 2.4$ & ND & $3.6 \pm 0.6$ & $20.0 \pm 0.3$ \\
\hline \multicolumn{7}{|c|}{ FCx10 ${ }^{3}$ MPN g $^{-1} /$ Site } \\
\hline Winter & ND & $0.2 \pm 0.7$ & $3.7 \pm 0.3$ & ND & $0.4 \pm 1.3$ & $3.4 \pm 0.4$ \\
\hline Spring & $0.1 \pm 0.3$ & $2.0 \pm 1.0$ & $41.0 \pm 0.9$ & ND & $5.0 \pm 1.4$ & $21.0 \pm 2.5$ \\
\hline Summer & ND & $28.0 \pm 0.6$ & $320 \pm 1.0$ & $0.3 \pm 1.3$ & $46.0 \pm 1.7$ & $300 \pm 1.0$ \\
\hline Summer & ND & $0.5 \pm 1.9$ & $4.2 \pm 1.8$ & ND & $0.7 \pm 1.2$ & $3.5 \pm 2.6$ \\
\hline \multicolumn{7}{|c|}{$\mathrm{AHx}^{13} \mathrm{CFU} \mathrm{g}^{-1} /$ Site } \\
\hline Winter & $0.17 \pm 0.6$ & $1.7 \pm 0.8$ & $18 \pm 0.6$ & $0.21 \pm 0.7$ & $2.8 \pm 0.5$ & $31.0 \pm 1.2$ \\
\hline Spring & $0.26 \pm 0.9$ & $3.4 \pm 1.9$ & $310 \pm 0.2$ & $0.32 \pm 0.4$ & $5.6 \pm 1.3$ & $510 \pm 0.4$ \\
\hline Summer & $0.48 \pm 1.5$ & $40.0 \pm 1.2$ & $350 \pm 08$ & $0.58 \pm 2.0$ & $44.0 \pm 2.5$ & $420 \pm 0.6$ \\
\hline Autumn & $0.24 \pm 0.8$ & $3.7 \pm 1.0$ & $24 \pm 0.2$ & $0.45 \pm 1.5$ & $4.0 \pm 0.4$ & $38.0 \pm 1.6$ \\
\hline \multicolumn{7}{|c|}{$\mathrm{SAx}^{10} \mathrm{CFU} \mathrm{g}^{-1} /$ Site } \\
\hline Winter & ND & $1.5 \pm 1.0$ & $2.1 \pm 0.7$ & ND & $0.29 \pm 0.3$ & $14.0 \pm 0.6$ \\
\hline Spring & ND & $3.4 \pm 0.2$ & $27.0 \pm 0.8$ & ND & $4.5 \pm 0.9$ & $376 \pm 0.2$ \\
\hline Summer & $0.35 \pm 1.3$ & $45.0 \pm 1.1$ & $446 \pm 0.7$ & $0.56 \pm 0.2$ & $860 \pm 1.3$ & $476 \pm 0.1$ \\
\hline Autumn & ND & $2.4 \pm 0.4$ & $7.6 \pm 0.7$ & ND & $1.6 \pm 0.3$ & $23.0 \pm 0.3$ \\
\hline \multicolumn{7}{|c|}{ PAx 10 $^{3} \quad$ MPN g $^{-1} /$ Site } \\
\hline Winter & ND & $0.1 \pm 0.4$ & $1.6 \pm 0.3$ & ND & $0.26 \pm 0.9$ & $0.32 \pm 0.8$ \\
\hline Spring & ND & $2.0 \pm 0.8$ & $3.6 \pm 0.5$ & $0.2 \pm 0.7$ & $1.30 \pm 0.3$ & $3.3 \pm 2.6$ \\
\hline Summer & $0.1 \pm 0.3$ & $5.0 \pm 1.7$ & $4.6 \pm 1.0$ & $0.4 \pm 1.3$ & $24.0 \pm 0.2$ & $61.0 \pm 0.9$ \\
\hline Autumn & ND & $0.2 \pm 0.6$ & $2.5 \pm 0.2$ & ND & $0.41 \pm 2.4$ & $0.29 \pm 0.5$ \\
\hline
\end{tabular}

*TC: Total coliform; FC: Fecal coliform; AH: Aeromonas hydrophila; SA: Staphylococcus aureus and PA: Pseudomonas aeruginosa.

\section{Isolation and identification of pathogenic bacteria}

A total of 152 isolates of $S$. aureus and 135 of $P$. aeruginosa were collected from fish and water samples, All $S$. aureus isolates produced black, shiny, convex colonies on Vogel and Johnson agar medium, golden yellow colonies on mannitol salt agar. They were coagulase positive. $P$. aeruginosa isolates produced purple- red color on acetamide agar medium and green fluorescent color in Pseudomonas asparagine agar media. Selected isolates from $S$. aureus and $P$. aeruginosa were identified using BIOLOG GEN III system (BIOLOG, USA).

A total of 219 isolates from fish and water samples were identified as $A$. hydrophila by conventional method, they produce yellow and green colonies on mAeromonas medium. They were Gram negative motile bacteria. They were positive for Voges-Proskouer test, cytochrome oxidase test, D-glucose fermentation, arginine dihydrolase ornithine decarboxylase and o-nitrophenyl-B-D-galactopyranoside test. They produced $\mathrm{H} 2 \mathrm{~S}$ from cysteine, hydrolysed escuslin, L-arabinose.

\section{Molecular detection of aerolysin gene in $A$. hydrophila isolates}

Amplification of a 431 bp of aerolysin gene (a virulence gene of $A$. hydrophila) was carried out for all $A$. hydrophila isolates Fig. (2). Results showed that 158/219 (72\%) were confirmed as $A$. hydrophila harboring aerolysin toxin gene Table (4). Results showed that the aerolysin carrier $A$. hydrophila in mullet were 64.2, 66.6 and $60 \%$ in muscles, liver and gills respectively. Whereas, in mullet the percentages were 62,80 and $74 \%$ respectively. 
Table 4: Detection of aerolysin gene in Aeromonas hydrophila isolated from water and fish of Lake Qaroun.

\begin{tabular}{|c|c|c|c|c|}
\hline \multirow{2}{*}{ Sample } & \multirow{2}{*}{ source } & \multicolumn{2}{|c|}{ No. of A. hydrophila } \\
\cline { 3 - 5 } & & conventional method & aerolysin gene positive \\
\hline \multirow{4}{*}{ Water } & Site I & 32 & 25 \\
\cline { 2 - 4 } & Site II & 25 & 18 \\
\cline { 2 - 5 } & Site III & 22 & 17 \\
\cline { 2 - 5 } & \multicolumn{2}{|c|}{ Site IV } & 19 & 15 \\
\hline \multirow{4}{*}{ Fish } & \multirow{3}{*}{ Tilapia } & Muscle & 14 & 9 \\
\cline { 3 - 5 } & \multirow{3}{*}{ Mullet } & Liver & 18 & 12 \\
\cline { 3 - 5 } & & Gills & 25 & 15 \\
\cline { 3 - 5 } & & Muscle & 16 & 10 \\
\cline { 3 - 5 } & & Liver & 21 & 20 \\
\hline & Gills & 27 & 158 \\
\hline \multicolumn{2}{|c|}{ Total isolates } & 219 & \\
\hline
\end{tabular}

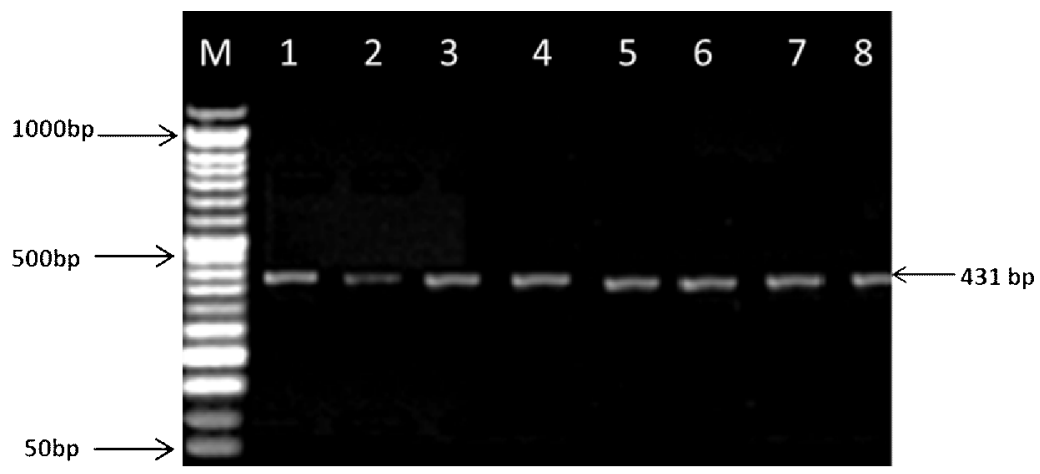

Fig. 2: PCR amplification of 431 bp of aerolysin gene from Aeromonas hydrophila isolates. Lane M, DNA ladder, lanes 1-4 isolates from water samples and lanes 5-8 isolates from fish samples.

\section{DISCUSSION}

Physiochemical characteristics of Qaroun lake were monitored during 12 months and the results varied according to the parameters and sites. Temperature is one of the most important factors affecting aquatic organisms likewise the chemical and physical characteristics of the water (Abdo, 2003; Haroon et al., 2018). The changes in temperature values rely mainly upon the seasonal variation, time of sampling and additionally influenced by special characteristics of water environment such as degree of transparence, wind force and evaporation (Mahmoud, 2002; Tayel, 2002). In the current study, the $\mathrm{pH}$ values of the water was slightly alkaline (7.5 - 8.5) which favored bacterial growth, also, the decrease in surface water salinity in site (I) which was a consequence of the enlarged human activities and the outflow of wastewater and their circulation into the lake water (Shabaan et al., 2016). On the other hand, site I which is only $2 \mathrm{Km}$ away from El- Batts drain showed the lowest values of dissolved oxygen (DO) especially in summer $4.1 \mathrm{mgO}_{2} / 1$, due to high organic matter and the bacterial activity in this area, in addition the high chemical oxygen demand (COD) in site I , indicated a greater amount of oxidizable organic material in the samples in this site, which in turn decrease the dissolved oxygen which affect the aquatic life and caused stress on aquatic animals and plants. High levels of ammonia, nitrite, nitrate and phosphorus were also recorded which might contribute to the introduction of inorganic or organic fractions through anthropogenic sources (Abou El-Gheit et al., 2012). 
The bacteriological characteristics of Qaroun lake showed that the effluent of El Batts drain in site I had higher bacterial count than the other sites in Qaroun lake water. It is obvious that El-Batts drain exceeded the acceptable values for drainage water discharged into the lake. According to Egyptian Environmental Law (No.48, 1982), the accepted guide values of coliform bacteria in drainage water is $5000 / 100$ $\mathrm{ml}$ water. This is an evidence of the absence of sanitary coverage in rural area around the drain, which leads to onsite discharge of untreated wastewater into the drain or some of this bacterial load may originate from soil.

The loads of different bacteria observed in water samples taken from Qaroun lake were higher than the recommended values for fish culture according to the Egyptian standard at which 70/100 ml water of the lake for total coliform bacteria is accepted (Shabaan et al., 2016). The higher density of bacteria in fish collected from Qaroun lake is suggested to be due to the increase in pollution levels in the lake in addition, the high water temperature which was close to the optimum temperature for many mesophilic bacteria in natural system (Isobe et al., 2004).

Fishery products are important not only from a nutritional point of view, but also as an item of international trade and foreign exchange earner for a number of countries in the world (Shabaan et al., 2016). Fish can function as carriers of several microbial and other health hazards. Though, in this study total and fecal coliforms were detected in tilapia and mullet fish, it was found that the bacterial count in mullet organs were higher than in tilapia, this data was in agreement with Aman et al. (2018) who reported the higher total and fecal coliform count in mullet than tilapia, this can be due to the increase of lipid content in mullet than tilapia. Total and fecal coliform were detected twice in muscles during the period of study in summer and spring. The microbiological diversity of the fish muscle depends on the environmental factors around it. In addition to, non-hygienic fishing methods of small-scale fishermen using small engine boats, nets or hooks for fishing which might cause cross contamination and hence poor quality of fish are presented to the consumers (Mhango et al., 2010).

Bacterial pathogens are a great threat to fish production worldwide (Wamala et al., 2018). Fish have great capacity to move, therefore, it is able to carry pathogenic bacteria to non-polluted waters causing infection for humans when consumed or handled (De Guzman, 2004). Infections caused by aeromonad in fish were mostly reported to be associated with $A$. hydrophila. It is an opportunistic microorganism (Sarder et al., 2016 ). Results in this study pointed out that the highest density of $A$. hydrophila was recorded in summer followed by spring. These results were supported by Shabaan et al. (2016) and Daniel et al. (2006) who recorded that A. hydrophila have been recovered in abundance from lakes particularly in warm temperatures. $A$. hydrophila were detected in the muscles of the two studied fish all the year. While bacterial indicators, $S$. aureus and $P$. aeruginosa were detected once to three times only during the year. This may be due to A. hydrophila is considered a truly opportunistic pathogen, because it is relatively common in the aquaculture environment and typically does not cause disease in healthy, well maintained fish population (Yanong and Francis-Floyd, 2002). The increase of pathogen is related to stress that plays a significant role in outbreaks of infectious disease in fish populations. Some stressors such as high water temperatures (e.g., during the summer), high stocking densities, harvesting or handling, and poor water quality, such as high ammonia or nitrite concentrations have been associated with Aeromonas spp. outbreaks. This was confirmed by Abou El-Gheit et al. (2012) who reported that facultative microbial fish pathogens as Aeromonas spp. are continuously present in water and carrier fish in Qaroun lake fish. While, the confirmation of $A$. hydrophila 
has been carried out by amplification of aerolysin gene (Singh et al., 2008; Oliveira, et al, 2012). Aerolysin is a hemolytic toxin encoded by aerolysin gene that plays a key role in the pathogenicity of A. hydrophila infection in fish. Molecular detection of this gene was carried out using a specific PCR primer. Bunyan and Obais (2018) reported that the distribution of aerolysin gene reach $(85.7 \%)$ of the A. hydrophila. Aerolysin was the most common factor described in $A$. hydrophila isolates; the presence of aerolysin is a strong indication of virulence in pathogenic isolates of Aeromonas spp.(Heuzenroeder et al., 1999). PCR assay utilized in the current study proved to be a useful diagnostic tool for $A$. hydrophila detection using aerolysin gene as genetic virulence marker. Rapid detection of $A$. hydrophila has confirmed importance with the purpose of proper, rapid preventive as well as control measures could be taken up to decline mortality also loss in fish culture.

With regards to, the results of Staphylococcus aureus in water samples from Qaroun lake.It was fluctuated from minimum of $1.5 \times 10^{2} \mathrm{CFU} / 100 \mathrm{ml}$ in site (IV) to maximum $9.5 \times 10^{4} \mathrm{CFU} / 100 \mathrm{ml}$ in site (I). This is fairly less than the records of Shabaan et al. (2016) who recorded that Staphylococcus spp. ranged between 5.0 $\times 10^{2}$ and $9.55 \times 10^{4} \mathrm{CFU} / \mathrm{ml}$. This may be attributed to differences in geographical distribution of water samples, time of sampling during different months. In addition, the increases or decreases of drainage waters in the lake which heavily loaded with wastes, salts, nutrients, pesticides, heavy metals and organics that may accumulate and contaminate the aquatic environment (Khalaf-Allah, 2014). Although S. aureus is not difficult to grow and is easy to identify, there is a need for the development of rapid and sensitive DNA-based assays more suitable for the direct detection of $S$. aureus from clinical specimens to improve the rapidity and the accuracy of the diagnosis of $S$. aureus infections. The result of PCR assay in current study revealed positive amplification of $S$. aureus. These results suggest that the PCR assay could be used as an alternative method in routine diagnosis for rapid, sensitive, and specific simultaneous detection of $S$. aureus in fish samples (Atwa, 2017).

Pseudomonades are opportunistic Gram negative pathogens, naturally occur in aquatic environment and as a part of normal gut flora of healthy fish, it causes outbreak when the optimum environmental conditions change. Pseudomonas species have been described as etiological agents of diseases in fish in Egypt (El-Nagar, 2010). Moreover, various Pseudomonas species infected Qaroun lake fish and caused septicemia in Tilapia spp. (Eissa et al., 2010). In this study P. aeruginosa were isolated from muscle, gills and liver of fish. This result is in agreement with Tesfaye et al. (2018) who reported that the presence of Pseudomonas species from different parts of fish.

\section{CONCLUSION}

This study highlights the danger of the high prevalence of bacterial pathogens in Lake Qaroun fish as A. hydrophila, P. aeruginosa and S. aureus. El-Batts drain has a devastating effect on the lake. Thus, urgent treatment should be done before discharging wastes into the lake.

\section{ACKNOWLEDGEMENT}

The authors wish to thank Professor Gamila E. El-Taweel, professor of Microbiology, Centre of Excellence for Advanced Science (CEAS), Water Pollution Research Department, National Research Centre, Giza, Egypt., for her valuable help, continuous support and guidance through out this work. 


\section{REFERENCES}

Abd-El-Malek, A. M. (2017). Incidence and virulence characteristics of Aeromonas spp. in fish. Vet. World, 10 (1): 34-37.

Abdo, M. H. (2003). Physico-chemical characteristic of Abu Zabaal ponds, Egypt. Egypt. J. Aquat. Res., 31 (2): 1- 15.

Abou El-Geit, E.; Saad, T.; Abdo, M. and Mona, S. Z. (2013). Microbial infections among some fishes and crustacean species during blooming phenomenon in Qaroun Lake-Egypt. Life Sci. J., 10 (2): 1217-1224.

Abou El-Gheit, E. N.; Abdo, M. H. and Mahmoud, S. A. (2012). Impacts of Blooming Phenomenon on Water Quality andFishes in Qarun Lake, Egypt. Int. J. Environ. Sci. Eng., 3: 11- 23.

Aman, I. M.; Ali, Y. E.; Moustafa, N. Y. and Hamza, A. A. (2018). Quality assessment of Tilapia nilotica and Mugil cephalus fish from Egypt. J Vet Med Allied Sci, 2 (1): 1-6.

APHA (2012). APHA (American Public health Association). Standard methods for the examination of water and wastewater, $22^{\text {nd }}$ ed. Washington, D.C.

Atwa, E. I. (2017). Bacteriological Study of Fish Samples Collected from Different Markets in Some Egyptian Governorates and Antimicrobial Sensitivity of Isolates. Int. J. Curr. Microbiol. App. Sci., 6(5): 2765-2776.

Bunyan, I. A. and Obais, I. K. (2018). Genotypic Detection of Some Virulence Factors Among Aeromonas hydrophila Isolated from Diarrhea Cases (Iraq). J. Pure Appl. Microbiol., 12(1): 85-93.

De Guzman, A. B. and Torres, J. R. (2004). The University of Santo Tomas viewed from the lens of total quality management: Implications to total quality education. Asia Pac. Edu. Rev., 5(1): 88-99.

Eissa, N.; El-Ghiet, E. A.; Shaheen, A. and Abbass, A. (2010). Characterization of Pseudomonas species isolated from tilapia "Oreochromis niloticus" in Qaroun and Wadi-El-Rayan lakes, Egypt. Glob. Vet., 5(2): 116-121.

El-Gamal, A. M.; El-Gohary, M. S. and Gaafar, A. Y. (2018). Detection and Molecular Characterization of Some Bacteria Causing Skin Ulceration in Cultured Nile Tilapia (Oreochromis niloticus) in Kafr El-Sheikh Governorate. Int. J. Zool. Res., 14(1): 14-20.

El-Nagar, R. (2010). Bacteriological studies on Pseudomonas microorganisms in cultured fish. M.V.Sc. thesis, Faculty. Vet. Med., Zagazig. University.

El-Taweel, G. (2003). Association between Aeromonas spp. and classical bacterial indicators of pollution in different aquatic environments. Egypt J. Microbiol., 38: 265-282.

Elsayed, M.; Essawy, M.; Shabana, I.; Abou El-Atta, M. and EL-Banna, N. (2018). Studies on Bacterial Pathogens in Some Marine Fishes in EL-Mansoura, Egypt. Amer. J. Agric. Biol. Sci., 13(1): 9.15.

Falaise, C.; François, C.; Travers, M. A.; Morga, B.; Haure, J.; Tremblay, R.; Turcotte, F.; Pasetto, P.; Gastineau, R. and Hardivillier, Y. (2016). Antimicrobial compounds from eukaryotic microalgae against human pathogens and diseases in aquaculture. Mar. Drug., 14(9): 159.

Haroon, A. M.; Hussian, A. E. M. and El-Sayed, S. M. (2018). Deviations in the biochemical structure of some macroalgal species and their relation to the environmental conditions in Qarun Lake, Egypt. Egypt J. Aquat. Res., 44: 1520 . 
Heuzenroeder, M. W.; Wong, C. Y. and Flower, R. (1999). Distribution of two hemolytic toxin genes in clinical and environmental isolates of Aeromonas spp.: correlation with virulence in a suckling mouse model. FEMS. Microbiol. Lett., 174(1): 131-136.

Howard, S.; Garland, W.; Green, M. and Buckley, J. (1987). Nucleotide sequence of the gene for the hole-forming toxin aerolysin of Aeromonas hydrophila. J. Bacteriol., 169(6): 2869-2871.

Hussein, H.; Amer, R.; Gaballah, A.; Refaat , Y. and and Abdel-Wahab, A. (2008). Pollution Monitoring for Lake Qarun. Adv. Environ. Biol., 2(2): 70-80.

Isobe, K. O.; Tarao, M.; Chiem, N. H.; Minh, L. Y. and Takada, H. (2004). Effect of environmental factors on the relationship between concentrations of coprostanol and fecal indicator bacteria in tropical (Mekong Delta) and temperate (Tokyo) freshwaters. Appl. Environ. Microbiol., 70: 814-821.

Khalaf-Allah, H. (2014). Seasonal distribution and abundance of small fish in the south coast of Lake Qarun, Egypt. World J. Fish Mar. Sci., 6 (1): 109-118. .

Leiser, W. L.; Rattunde, H. F. W.; Piepho, H.P.; Weltzien, E.; Diallo, A.; Toure, A. and Haussmann, B. I. (2015). Phosphorous efficiency and tolerance traits for selection of sorghum for performance in phosphorous-limited environments. Crop Sci., 55: 1152-1162.

Mahmoud, S. (2002). Evaluation of toxicity effect of some pollutants on histological feature and biochemical composition of Oreochromis niloticus living in River Nile (Damietta branch). Ph. D. Thesis, Fac. of Sci., Benha Branch, Zagazig Univ. Egypt.

Mhango, M.; Mpuchane, S. and Mpuchane, B. (2010). Incidence of indicator organisms, opportunistic and pathogenic bacteria in fish. Afri. J. Food Agr. Nutr. Devel., 10.(10): 4202-4218.

Oliveira, S.; Veneroni-Gouveia, G. and Costa, M. (2012). Molecular characterization of virulence factors in Aeromonas hydrophila obtained from fish. Pesqui. Vet. Brasil., 32(6): 701-706.

Patil, P. N.; Sawant, D. V. and Deshmukh, R. (2012). Physico-chemical parameters for testing of water-A review. Int. J. Environ. Sci., 3(3): 1194.

Rippey, S. and Cabelli, V. (1979). Membrane filter procedure for enumeration of Aeromonas hydrophila in fresh waters. Appl. Environ. Microbiol., 38(1): 108113.

Sarder, H.; Khan, S.; Saha, M. L.; Punom, N. J.; Mandal, S. C. and Rahman, M. S. (2016). Prevalence and antibiotic susceptibility of Aeromonas hydrophila isolated from fresh water fishes J. Fish., 4 (3): 411-419.

Seshadri, R.; Joseph, S. W.; Chopra, A. K.; Sha, J.; Shaw, J.; Graf, J.; Haft, D.; Wu, M.; Ren, Q. and Rosovitz, M. (2006). Genome sequence of Aeromonas hydrophila ATCC 7966T: jack of all trades. J. Bacteriol., 188 (23): 8272-8282.

Shabaan, T. M.; Ibrahim, H. A. H. and Hanafi, A. A. (2016). Distribution of bacteria in Lake Qarun, AL Fayoum, Egypt (2014 -2015) in relation to its physical and hydrochemical characterization. J. Biosci. Appl. Res., 2(9):601-615.

Singh, V.; Rathore, G.; Kapoor, D.; Mishra, B. N. and Lakra, W. S. (2008). Detection of aerolysin gene in Aeromonas hydrophila isolated from fish and pond water. Indian. J. Microbiol., 48(4): 53-458.

Tayel, S. (2002). Histological biochemical and hematological studies on Ttilipia zilli and Clarios lazera in relation to water quality criteria at different locations in Delta Barrage. PhD Thesis, Faculty of Science, Banha Branch, Zagazig University, Egypt. 
Tesfaye, S.; Kasye, M.; Chane, M.; Bogale, B. and Abebe agere, Z. (2018). Preliminary Survey of Gram-Negative Bacterial Pathogens from Commonly Caught Fish Species (Oreochromis niloticus, Cyprinus carpio and Clarias gariepinus) in Lake Hayiq, Ethiopia. Fish Aqua. J., 9(1): 238. doi:10.4172/2150-3508.1000238.

Vogel, T. A. and Johnson, M. (1960). A modification of the tellurite -glycine medium for use in the identification of Staphylococcus aureus.Public Health Lab., 18:131.

Wamala, S.; Mugimba, K.; Mutoloki, S.; Evensen, Ø.; Mdegela, R.; Byarugaba, D. and Sørum, H. (2018). Occurrence and antibiotic susceptibility of fish bacteria isolated from Oreochromis niloticus (Nile tilapia) and Clarias gariepinus (African catfish) in Uganda. Fish Aquat. Sci., 21(6):2-10.

Yanong, R. P. and Francis-Floyd, R. (2002). Streptococcal infections of fish. Florida Cooperative Extension Service. IFAS, University of Florida. 1-5. 